\title{
Life and Death on the Pulse Dance Floor: \\ transglocal politics and the Erasure of the latinx in THE History of QUeER DANCE
}

\author{
$\because$ Feature Article $\longrightarrow$ \\ TIM LAWRENCE \\ UNIVERSITY OF EAST LONDON (UK)
}

\begin{abstract}
Although the dominant response of politicians, journalists and campaign groups to Omar Mateen's 12 June 2016 massacre of forty-nine people at the Pulse nightclub in Orlando revolved around the repetition of already established arguments about terrorism, this article will outline how the massacre amounted to a specific attack on the Latinx community. ${ }^{1}$ It will also argue that, although distinctive, the discursive erasure of the specifically queer Latinx finds a partial echo in the way that Latin culture has been marginalised in writing on dance culture. An outline map of the somewhat opaque Latinx contribution will be offered as a small tribute to those who have lived for and now died on the Latinx dance floor. The account of the dancers who gathered at Pulse, the music they danced to, and the unstable, marginalised and dynamic networks of musicians, dancers and party spaces that preceded them will be considered within J. Blake Scott and Rebecca Dingo's (2012) evocation of the "transglocal". If transglocal encounters "can generate new meanings and subject positions" (Blake Scott and Dingo: 7), so the dancers at Pulse can be seen to have moved resourcefully, dynamically and creatively between the local and the transnational as they sought out new modes of expression and community in a darkening global terrain.
\end{abstract}

KeYwords: Pulse, Orlando; Latinx; LGBTQ; DJ culture; terrorism

Tim LAWRence is a professor of Cultural Studies at the University of East London. He is the author of Love Saves the Day: A History of American Dance Music Culture, 1970-79, Hold On to Your Dreams: Arthur Russell and the Downtown Music Scene, 1973-92, and Life and Death on the New York Dance Floor, 1980-83, all with Duke University Press. He is the co-founder of the Centre for Cultural Studies Research and Lucky Cloud Sound System. < www.timlawrence.info $>$.

\footnotetext{
Dancecult: Journal of Electronic Dance Music Culture 8(1): 1-25 ISSN 1947-5403 @2016 Dancecult http://dj.dancecult.net http://dx.doi.org/10.12801/1947-5403.2016.08.01.01 
Deepening divisions in the US political landscape (Berman: 2016), combined with social media's decimation of the once seemingly frenetic twenty-four hour news cycle (Alejandro 2010), fueled the near-instantaneous rationalisation of the Pulse massacre through the prism of ongoing debates about terrorism and gun control. Presumptive Republican presidential candidate Donald Trump had already thrown out the casually fascistic suggestion that all Muslims should be banned from entering the US when he tweeted: "Appreciate the congrats for being right on radical Islamic terrorism, I don't want congrats, I want toughness \& vigilance. We must be smart!" (Trump 2016). Obama described the attack as "act of terror and an act of hate", and although he remarked that the place where LGBT Americans "were attacked is more than a nightclub-it is a place of solidarity and empowerment where people have come together to raise awareness, to speak their minds, and to advocate for their civil rights" - he maintained that "this could have been any one of our communities", that an attack on "any American [...] is an attack on all of us", and that the massacre served as a "further reminder" of the need for gun control (Time 2016). Presumptive Democratic presidential candidate Hilary Clinton framed the massacre as both "an act of terror" and an "act of hate", and pointed to the need to defeat "international terror groups" and keep guns "out of the hands of terrorists" (Briefing 2016). The New York Times summarised the massacre as "a tragedy that combined gun violence, a hatred of gays and ties to Islamist terrorism” (Shear 2016).

Talk of terrorism, the nation and the West escalated to the point where the specificity of the massacre became hard to discern. Barely twelve hours after it had elapsed Adam Schiff of the House Intelligence Committee declared that evidence indicates "an ISISinspired act of terrorism" (New York Times 2016). The following day FBI Director James Comey noted that despite there being no indication of outside direction the intelligence community was "highly confident that this killer was radicalized at least in part through the Internet" (Shabad 2016). Two days later the FBI agent in charge of the investigation called the massacre both a hate crime and an act of terrorism (RT.com 2016). Meanwhile it took the Republican governor of Florida Rick Scott almost forty-eight hours to recognise that the massacre was perpetrated against the LGBT community, with Florida's attorney general Pam Bondi equally evasive (Wolf 2016). In the UK commentator Owen Jones left Sky TV's studios when presenters insisted that the attack wasn't homophobic, after which the Irish Independent rounded on Jones for failing to point out that the homophobic attack was "religiously motivated" and for propagating "identity politics at its most exclusionary and grotesque" (O’Doherty 2016). Some weeks later the FBI maintained that the investigation "hasn't revealed that he [Mateen] targeted Pulse because it was a gay club" (Goldman 2016). Even if the scale of the shooting was undeniably shocking, it also became commonplace to overstate Mateen's spree as the "deadliest" in US history (Breen 2016; Broverman 2016; Guardian 2016; Ravitz 2016; Teague 2016), situating it as an attack on the nation while papering over bloodier massacres perpetrated against Native Americans. 
In fact, the framing of Mateen as an Isis-inspired terrorist was based on spurious evidence. $\mathrm{He}$ attended his local mosque, the Islamic Center of Fort Pierce, but only infrequently. $\mathrm{He}$ twice went to Saudi Arabia on a pilgrimage in 2011 and 2012 to perform umrah, making him one of six million Muslims who do so annually. In 2013 he claimed to be aligned to both al-Qaeda and Hezbollah, and citing two groups who are sworn Sunni-Shiite enemies. Concerned when it heard about these claims, the FBI investigated Mateen only to close its inquiry when he explained he had made the comment in response to being teased for his Muslim faith. A further FBI investigation into possible links between Mateen and a US citizen from the same mosque in Fort Pierce who took part in an al-Qaeda affiliate attack led nowhere. Mateen's claim to know people who were linked to the brothers who carried out the Boston Marathon bombing turned out to be fictional. On the Saturday before the massacre he posted messages declaring his allegiance to the leader of Isis, calling on the U.S. and Russia to stop bombing Isis, but the declaration bore no relation to patterns of strict religious conduct or ideological support of Isis. All the same, a CBS poll published on 15 June showed that three-quarters of US citizens believed Mateen's attack was either an act of terrorism or an act of terrorism as well as a hate crime, while Wikipedia reported matterof-factly that the massacre constituted "the deadliest terrorist attack in the U.S." since 9/11 (Salvanto et al 2016; Wikipedia 2016).

The depiction of Mateen as typical of the Orientalist male outlined by Edward Said (1995) - effeminate yet sadistic, simple yet duplicitous, outwardly functional yet psychologically unstable, intelligent yet irrational—provided further presumptive evidence that his actions were driven by so-called Islamic terrorism. Abusive behaviour within his first marriage appeared to affirm long held views about patriarchal violence within Islam while parallel stories of his pursuit of sexual encounters with other men via the gay dating app Grindr as well as the Pulse dance floor raised the thought that the massacre was rooted in his inability to reconcile his sexuality with his religion, which was repeatedly cited as being intolerant of homosexuality. Reports of Mateen's increasingly angry demeanour, including a certain broodiness displayed during some of his visits to Pulse, pointed to an individual wrestling with conflicting cultural affinities and desires that were bound to culminate in an uncontrollable explosion. Citing no sources, the Guardian linked the massacre to Islam when it reported that Mateen was "said to have enrolled in online courses taught by a homophobic imam" and added that "homophobia and jihadism are anything but mutually exclusive" inasmuch as "Isis executes people it says are gay, stones them and throws them from roofs" (Ackerman and Siddiqui 2016). Particular prominence was given to Mateen's father's Facebook video comment that "God himself will punish those involved in homosexuality" (Sullivan and Wan 2016). Referring to the father's story of his son's expression of revulsion when he saw two gay men kissing while spending time with his second wife and son, the Washington Post noted that if Mateen was "interested in men, it would have been difficult to tell his father" before asking: "Was it Islamic State ideology or some personal demon that drove him to target gay people?" (Sullivan and Wan 2016). 
The overall depiction reaffirms Jasbir K. Puar's argument that constructions of terror and terrorist masculinities are "metonymically tied to all sorts of pathologies of the mind and body" as well as permeated by "perverse, improperly hetero- and homo- Muslim sexualities" (Puar: xxiii-xxiv). Puar and Amit Rai note how the personality defect model has been developed within Terrorism Studies as one of two main explanations of the "terrorist mindset", with terrorists assumed to display pathological defects that are rooted in unconscious feelings of hostility towards their parents (perhaps because of abuse or adolescent rebellion) or of exaggerated identification (perhaps because of perceived suffering experienced by their parents) before the pathology becomes narrow, extreme and absolutist in adulthood. It follows that if terrorism is a symptom of a deviant psyche, or the breakdown of the psyche of the heterosexual family romance, then monster-terrorists are products of a form of "failed heterosexuality" (Puar and Rai: 124).

Yet people who experience sexual conflicts or display psychotic symptoms don't inevitably go on to carry out terrorist attacks, just as the people who carry out such attacks aren't necessarily conflicted or psychotic, and while it remains possible that more compelling evidence will come to light, for now Sima Shakhsari is right to suggest that Mateen's lastminute declaration of allegiance to Isis might well have been made to give a "heroic" gloss to his homophobia, with Isis a "deterritorialized imagined community where anyone who wants to defy certain social rules can claim belonging (or is assigned belonging)" (Shakhsari 2016). Ultimately the terrorist label stuck to Mateen because of his Afghan background and Islamic heritage, just as, conversely, no terrorist sympathies were attached to the white man who was arrested before carrying out a planned attack at Pride in Los Angeles on the same day as Mateen carried out his massacre. "The Muslim feigns patriotism and practice of American customs, but it is a trick, so he must be watched for signs of savagery as he prays in the mosque and goes about his business", notes Roqayah Chamseddine of the Orientalist view of the Muslim. "The Muslim American is a hyper-visible yet invisible being who will have his American-ness stripped from him the moment he errs" (Chamseddine 2016).

The rush to affirm Mateen's pathological terrorist intent just so happens to support a nationalist discourse that positions the US as the hub of global democracy, liberalism and morality, with a generalised Islamic East posited as an overt or covert threat to those values and their associated way of life. In perhaps the most remarkable of these interventions, Trump, not previously renowned for his dedication to LGBTQ rights, figured the attack on "gay and lesbian citizens" as "a strike at the heart and soul of who we are as a nation" because it enabled him to figure the liberal West as being at war with illiberal Islam, thereby justifying his proposal to ban Muslims from entering the US. "The bottom line is that the only reason the killer was in America in the first place was because we allowed his family to come here", he argued, adding that Mateen's father comes from a culture where $99 \%$ of people support Sharia Law (Trump 2016). "That is a fact, and it's a fact we need to talk about". 
As much as Trump's claims to liberalism might amaze, his contention sits within a widely accepted discourse that gives the US permission to enact illiberal policies, ranging from foreign wars to the maintenance of Guantanamo Bay to the policing of people of colour, in order to defend its claim to being the bastion of western liberalism. To point this out is not to argue for the equivalence or non-equivalence of the US vs. the Rest so much as to note that, for all of the talk about US tolerance, including freedom for its LGBTQ citizens, levels of homophobia, racism and sexism remain high-one might even say surprisingly high given these underpinning claims to liberalism. Puar (2007 2) also points to the relatively recent rise of homonationalism, or a form of nationalism that embraces the idea of LGTBQ rights and policies around, say, gay marriage so long as those embraced under this banner are willing to articulate the nationalist concerns of the political establishment. In this manner queer liberals have been coopted to a cause that is quick to support the introduction illiberal measures to defend liberalism.

Meanwhile Muslim countries, intent on preserving relations with the US, lined up to denounce Isis and distance themselves from its ideology; Saudi Arabia’s problematic ties with Isis along with the United States's generally strong diplomatic ties with Saudi Arabia passed all but unmentioned; and the silence surrounding the bombing campaign in Syria also escaped scrutiny (even if the post-Pulse panic strengthened its underlying rationale). Nor was any mention made of the fact that the horrendous death toll recorded at Pulse continued to be matched on a near daily basis in Iraq, as tracked by Iraq Body Count. ${ }^{2}$ Such are the power relations that underscored the way Mateen came to be defined in the hours that followed his attack. "In a war-on-terror world, there is an injunction to grieve in public for American lives lost to terrorism in order to ward off suspicion and further targeting", points out Maya Mikdashi (2016). "This injunction applies as well to the dead in France or Belgium, but not to victims of terrorism (state or otherwise) in Iraq or Nigeria or Syria. This phenomenon is directly related to the ways in which US political discourse on the war on terror has starkly divided the world into victims (Europeans and Americans) and perpetrators (Muslims and Arabs)".

As it happens the men who described their interactions with Mateen painted a picture of someone who enjoyed friendships with gay men and drag queens as well as someone who was able to differentiate between his own religious beliefs and the more conservative ideas of his father. In the longest testimony, a man going under the name of Miguel told Univision that he and Mateen had a relationship that was akin to being "friends with benefits" and that they met some 15-20 times in a hotel room over a two-month period before the relationship came to a close in December. "He say Muslim religion is a beautiful, beautiful religion", commented Miguel. "It's a religion where everything's about love, where everybody's welcome-gay, trans, bisexual, hetero, everybody”. He noted that Mateen never appeared to be violent. "He [was] looking for love", added Miguel. "To be embraced". Miguel hypothesised that Mateen carried out the attack as an act of revenge, angered that he might have become infected with HIV (even though the test came back negative) (Univision 2016). Other Pulse regulars remembered him as a sullen character, yet none 
recalled an individual unable to reconcile his desire with his religious beliefs-or a person who, assumed to be a frustrated gay Muslim, might channel his pent-up frustration on the very people his religion "forbade" him to desire, and in so doing give succour to the fake idea that being Islamic and queer could only result in that kind of rampage. Nor was there so much as a hint that Mateen lived his life according to the kind of hardline Wahhabist strictures advocated by Isis that might have made him want to carry out an attack on the group's behalf.

The gay community's response to the massacre expressed deep emotional shock while avoiding the easy temptation to characterise Mateen as a conflicted Muslim terrorist. At vigils staged across the world, speakers argued for the need to oppose those who sought to use the massacre as an excuse for anti-Muslim prejudice (Browne 2016). Yet they often did so from a compromised point-of-view, such as when Advocate editor Matthew Breen (2016) argued that talk of Isis was a "goddamned red herring" and that Mateen's hatred was "homegrown" inasmuch as it expressed societal homophobia, yet also recirculated the possibility that he was fuelled by Islamic extremism, with the Latinx identity of the Pulse crowd left invisible by his broader evocation of a generalised LGBTQ community. Courtney Fry (2016) followed up with a piece that noted the mainstream media's reluctance to identity the night as a queer night yet again generalised the attack by maintaining that all LGBTQ party spaces were now in "extreme danger" and that "a place that has always been known as an oasis from the bigotry, homophobia, transphobia, biphobia, physical threats, assaults, and murders that happen in the outside world, has now been torn to shreds".

The colourblind response spread to The Atlantic, which published research showing that "LGBT people are more than twice as likely to be the target of a violent hate-crime than Jews or black people", and "more than four times as likely as Muslims, and almost 14 times as likely as Latinos" (Green 2016), as if LGBTQ people couldn't be Jewish or black or Muslim or Latinx, as if killers could only be motivated "on the basis of one strand of hatred", and as if white LGBTQ people are "more vulnerable than other minority groups", as Jack Halberstam (2016) points out. A few days later the New York Times presented FBI data showing that LGBTQ people were the second most targeted group in 2005, behind "Jewish" and ahead of "Black", "Muslim", "Hispanic", "Asian" and "White", and were the most targeted group in 2014, only to note at the very bottom of the article the that "vast majority" of LGBTQ people killed were "black or Hispanic transgender people" (Park and Mykhyalyshyn 2016) - providing further evidence of the need, in Halberstam's words, to "challenge this sense of an amorphous homophobic threat that separates homophobic violence out from the particular, convulsive expressions of racialized hate" (2016). As research (Waters et al. 2016) on attacks carried out against LGBTQ people between 2012-15 published by the National Coalition of Anti-Violence Programs (NCAVP) reveals, white gay men were in fact the victims in eleven of a total of eighty-eight homicides, with the rest distributed between black transgender women (39), black gay men (11), Latinx transgender women (8) and other (19). 
It was primarily left to members of the Latinx queer community to note the erasure of the specificity of the attack. ${ }^{3}$ AM Foiles Sifuentes (2016) expressed her anger at the way "the same people that forced queer people of color to the margins are the ones hosting these public places of grieving" before asking: "Even in death — why is it okay for you to continue to force queer people of color to the margins? How can you find comfort in ignoring your collusion in their erasure?" Acknowledging the difficulty inherent in critiquing more powerful figures in the LGBTQ community because they also "shared in the vulnerability and trauma of the incident", Ramón Rivera-Servera pointed out reactions nevertheless "distanced themselves significantly from the specificity of this as a Latino, primarily Puerto Rican, experience" (Kornhaber 2016). Several writers cited Christina Hanhardt's (2012) research into the way past LGBTQ calls for anti-violence measures have often led to forms of increased policing that endanger queer people of colour and wider communities of colour. "The white LGBTQ community doesn't face the criminalization and policing that our community faces every day", remarked Jorge Gutierrez, founder of Familia: Trans Queer Liberation Movement (Vasquez 2016). "Not just at Pride, but every day, everywhere we go. That's our life".

The everyday homophobia and racism experienced by queer people of colour offers a more obvious explanatory context for Mateen's actions than any last-minute declaration of sympathy for Isis. There have, of course, been gains in the US in recent years, including the Supreme Court June ruling in Obergefell v. Hodges that effectively made same-sex marriage the law of the land, the White House LGBTQ pride reception where transgender

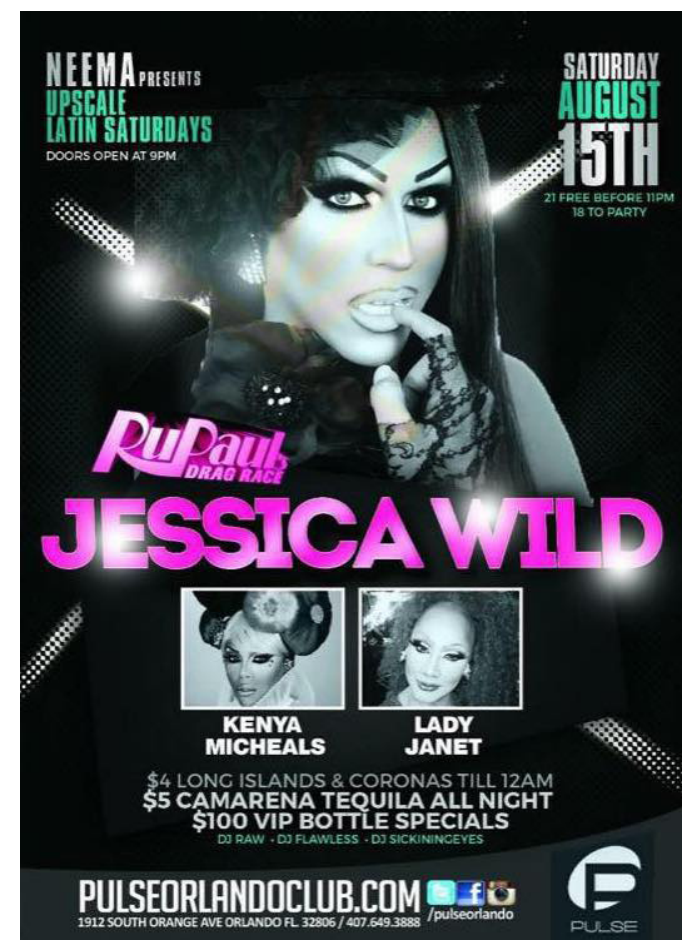

Figure 1: Flyer for Pulse's Saturday night parties. 
immigrant leader Jennicet Guttiérrez pointed to the plight faced by LGBTQ immigrants held in detention centres, and the Black Lives Matter movement's demanding an end to police violence and anti-black racism (Waters et al. 2016). Yet during the same period a slew of anti-LGBTQ initiatives swept the nation in the form of "religious freedom bills" and "bathroom bills" while racist and anti-immigrant rhetoric spiraled. If anything the backlash intensified during 2016, with eighty-seven bills aimed at limiting LGBTQ rights introduced in legislatures between January and June-a marked increase on previous years (Mason et al. 2016) - with police shootings of black men continuing apparently unabated. "Outside, they call you an abomination", author Justin Torres (2016) noted the day after Mateen's attack. "Outside, there is a news media that acts as if there are two sides to a debate over trans people using public bathrooms. Outside, there is a presidential candidate who has built a platform on erecting a wall between the United States and Mexico - and not only do people believe that crap is possible, they believe it is necessary. Outside, Puerto Rico is still a colony, being allowed to drown in debt, to suffer, without the right to file for bankruptcy, to protect itself. Outside, there are more than 100 bills targeting you, your choices, your people, pending in various states".

In terms of his personal location within this culture, Mateen sought out employment in violent settings and, perhaps not coincidentally, reproduced violent behaviour. He worked as a state prison guard at the Martin Correctional Institution and then for multinational security company G4S, a "hotbed of routine abuse, sexual violence, extremism and homophobia" where the "routine protection of violent, racist tendencies among its security officers appears to be an institutionalised global problem", according to Nafeez Ahmed (2016) of the Institute for Policy Research and Development. Mateen was sufficiently obsessed with the idea of working for the New York Police Department he took a series of selfies dressed in one of its shirts. Some acquaintances remember a person who littered his speech with the invective of hate. He took excessive quantities of steroids as he built himself up into a muscle machine and was a wife beater. He also committed his hate crime not against the United States, but against the Latinx LGBTQ dancers who congregated at Pulse that Saturday night - otherwise why travel two hours to Pulse instead of one of the city's two-thousand other bars?

Shakhasari (2016) wonders if it was Mateen's "performance of a homophobic and misogynistic American masculinity enabled by everyday militarism, and constructed visà-vis the 'failed masculinity' of the Muslim other, that led to this massacre". The critic acknowledges that the existence of violence, homophobia, transphobia and misogyny in the Middle East shouldn't mask the "hypocrisy of an exceptionalism that assumes the US to be the bastion of freedom and progress". Mateen's expression of homophobic and violent sentiments might not offer final proof of his motivations, but in the final instance his actions were much more obviously homophobic and violent than inspired by the ideology of Isis. 


\section{Writing the Latinx Dance Floor into Pulse and the History of Dance CULTURE}

What, then, of the population that Mateen attacked-a population that has been, to varying degrees, left out of accounts of the massacre? Barbara Pomo and Ron Legler founded Pulse in 2004 in honour of Pomo's brother, John, who died from AIDS in 1991, evoking his heartbeat in the club's name. Located at 1912 South Orange Avenue, the venue promoted itself as "the hottest gay bar in Orlando". Regular theme nights included Noche Latina on Mondays (featuring a Reggaetón dancehall soundtrack), Twisted Tuesdays (a talent night hosted by Axel Andrews and Kai'ja Adonis), College Night Wednesdays (hosted by Angelica Sanchez and weekly guests), Tease Thursdays (a burlesque show hosted by Lady Bri and Blade Matthews), Platinum Fridays (a hip hop night hosted by Angelica Sanchez) and Upscale Latin Night on Saturdays (hosted by former RuPaul's Drag Race contestant Kenya Michaels). Offering three rooms and a chic interior, the venue carried the promise of style, fabulousness and an escape from hardship. "Guests are free to choose which best suits their present mood", Diego Wyatt (2016) of Next Magazine reported in February. "Some fall under the spellbinding mystery of the Adonis Room, an intimate space filled with beautiful male and female go-go dancers. Some head to the Lounge, complete with a state-of-the-art lighting and sound system, a dance floor, VIP area and the main bar. And others go for the patio, which is undergoing some sprucing up to accommodate the relaxed atmosphere. Each area has its own DJ and vibe. Translation: There's something for everyone".

Prior to the attack the club attracted an eclectic crowd made up of LGBTQ people and straight friends of all ages and ethnicities, with Saturdays particularly popular with queer Latinx dancers. "I was too white to fit in with Latinos and I was too Hispanic to fit in with white kids", one told Matthew Rodriguez (2016) of mic.com. "But on Latino Night on Saturdays I didn't feel that way. It was just literally a time and place where everyone could be together and enjoy yourselves". Numerous drag performers got their start at the venue and indeed two trans women of colour were featured on publicity for the party that started on 11 June and ended with the massacre. Queer women were also a notable presence and, as Trish Bendixson (2016) notes, featured among the victims of the attack. Non-Latin migrantsincluding Mateen-were admitted into the mix. "I think Pulse differs from tourist clubs, as well as other local clubs, for a couple of reasons", Pomo commented in an interview with Billboard the day after the killing spree (Gray 2016). "One of our biggest goals was to create a warm, welcoming atmosphere that was family-like, with people who shared my vision".

Continuing the legacy established by pioneering party spots such as the Loft, the Sanctuary, the Haven and the Limelight in early 1970s New York City (Lawrence 2003), Pulse operated as cross between a home, a refuge, a community centre and a pleasure palace. "Growing up in a black and brown community where hyper-masculinity was acted out as a form of survival, I actually grew up hating on Pulse", dance floor regular Daniel Leon-Davis (2016) recounts in Fusion. "In my community, like in so many others around the world, my identity as a gay man was viewed as a form of weakness. So much so that even when I came 
out, I refused to go to gay clubs because it meant that I would be one of 'those gay men' ". Everything changed when he went to Pulse. "Over the next several years, Pulse became the place where my best friends learned to be themselves", he adds. "Pulse was where I learned to love myself as a gay man. Pulse was where I learned to love my community". Pomo also made a point of supporting local charities, raising funds for entertainers who wanted to enter pageants, educating around HIV/AIDS prevention and working in tandem with the straight community (Gray 2016). "We were never exclusive of any person's cause", she maintained in her Billboard interview. "Our doors were open to everyone". Pomo added: "People who aren't out, people who are exploring, people who are transitioning need a place to do this without judgment, they need acceptance; this is what Pulse was always about".

Operating at the intersection of race and class as well as sexuality and gender, Pulse is also rooted in the intertwining forces of colonialism and neoliberalism. With an estimated 1,000 Puerto Rican families currently relocating to Florida every month, the state is close to surpassing the total Puerto Rican population of New York (Alvarez 2016), and Orlando remains one of the primary destinations for this transitory population. The underpinning reasons for the movement are clear: Congress has historically refused to act on the unincorporated colony's seventy-billion dollar debt, leaving it unable to file for bankruptcy; its economy has stagnated since 2011; its population is declining; and its unemployment rate is twice as high as mainland US, with poverty three times as severe (Chappatta 2016). As US citizens Puerto Ricans are also free to travel to the mainland, with Florida offering them the nearest landing point in the US as well as access to employers such as SeaWorld Orlando Resort, Universal Orlando Resort, Walt Disney World Resort and Legoland. In August 2015 the New York Times observed that the current wave of migration "is transforming a corridor of Central Florida that is increasingly viewed as economically powerful, culturally diverse and politically pivotal" (Alvarez 2015). LGBTQ Puerto Ricans joined the migration to Orlando in part because of the city's nightlife, with its ten-plus gay bars matching the total in Detroit, a city three times Orlando's size, and Pulse offering queer migrants an opportunity to escape the "compulsory heterosexuality" (Rich 1980) of the city's theme parks. Pomo notes that LGBTQ holidaymakers would head to the club as well (Gray 2016).

Saturday 11 June started out as a regular Latin night with DJ Ray Rivera, a.k.a. DJ Infinite, selecting a mix of hip hop, R\&B and reggaeton, or "old school" as he put it in a Facebook exchange (Rivera 2016), with DJ Flawless and DJ Simo holding down the other two rooms. When Mateen began his rampage Rivera initially thought that someone was letting off firecrackers, reports Asawin Suebsaeng (2016); then he turned the music down and understood what was going on. Sourced from the biographical testimonies and photographs posted on social media by lovers, family members and friends, a person-byperson roll call of those who died conveys the connectedness as well as the pluralism of the social coalition that gathered on the floor that night (Mirkinson et al. 2016). "Maybe your Ma blessed you on the way out the door", Torres writes in his tribute to the dead, imagining the multiplicity of circumstances that might have preceded their congregation (Torres 2016). "Maybe she wrapped a plate for you in the fridge so you don't come home 


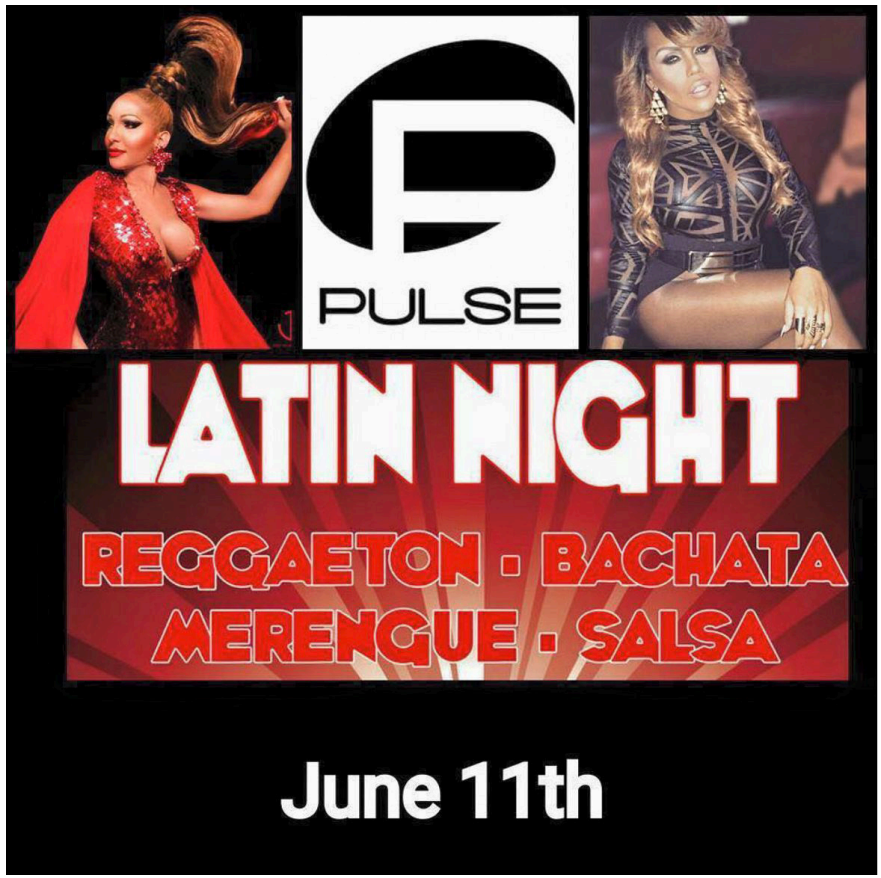

Figure 2: Flyer for the Saturday night party at Pulse on 11 June 2016.

and mess up her kitchen with your hunger. Maybe your Tia dropped you off, gave you cab money home. Maybe you had to get a sitter. Maybe you've yet to come out to your family at all, or maybe your family kicked you out years ago".

Torres offers further scenarios that articulate the way the sonic and social underpinnings of the Pulse dance floor stretch across time and space in transglocal fashion, to cite J. Blake Scott and Rebecca Dingo's (2012) evocation of culture combines the global and the local while "moving through space or across lines, as well as changing the nature of something", in the words of anthropologist Aihwa Ong (1999: 4). In the run-up to Mateen's attack the Pulse floor connected the disparate yet intertwining experiences of, to reference Torres's diverse community further, the dancer whose lover decided to stay at home to the one who is allowed to stray, the one who is flush to the one who is broke, the one who doesn't speak Spanish to the one who barely speaks English, and so on, until he finally asks after the dancer who might be undocumented, a common experience in the Latinx community, not solely in terms of the estimated eleven-million migrants who lack authorisation to live in the US (Kronstad and Passel 2015), but also in terms of societal location.

The lack of authorization extends to Latin music, which until recently barely figured in a field that was assumed to consist of a binary exchange between black and white musicians and listenerships. John Storm Roberts addressed the erasure when he argued that "Latin music has been the greatest outside influence on the popular music of the United States" (Roberts: ix), and Ned Sublette developed the analysis by showing how the "commonplaces of Cuban music became commonplaces of American music" (2004: 571) by 1951. Raquel Rivera carried the analysis to hip-hop, noting how New York Puerto Ricans were "integral" 
to the culture since its inception (2003:3). Ed Morales went on to trace the Latin influence on rock, hip hop and other sounds in Latin Beat: The Rhythms and Roots of Latin Music from Bossa Nova to Salsa and Beyond (2003), and Jim McCarthy and Ron Sansoe extended the analysis in the Voices of Latin Rock (2005). César Miguel Rondón's Spanish history of salsa came out in English three years later (2008), after which the authors of Reggaeton (2009) pointed to how the sound emerged as a transnational Jamaican, Nuyorican, Panamanian and Puerto Rican music with no singular place of origin. More recently, Juliet McMains (2015) has tracked the development of salsa dance in New York, Los Angeles and Miami as well as its relationship to salsa music. However, the Latin influence on DJ culture, disco, house music and other electronic dance sounds remains largely undocumented, and that left the impression that either the sound of the music or the sexuality of a significant number of its makers weren't sufficiently Latin, or weren't primed for easy integration into stories about national and diasporic musical movements. In this manner the queerest strand of Latinx culture has passed under-historicised, right up to the point when Mateen's assault on the culture revealed just how easy it remains to erase Latinx queerness.

Ramón H Rivera-Servera argues that the analysis of the utopian space of the queer Latinx dance floor requires an "engagement with the cultures of pleasure that characterize the club" as well as "the cultures of struggle that mark the multiple trajectories and negotiations undertaken by dancers on their way to and as a precondition for the utopian experiences of the dance floor" (2004: 271) What journeys, then, were undertaken in order for the dancers to congregate at Pulse on 11 June 2016, not only in terms of how they and the music they danced to coalesced that night, but also how previous generations of dancers and musicians (including DJs) combined to make Latinx dancers and Latin sounds become an integral part of DJ-led dance culture in the first place, from the pre-disco formation of the opening years of the 1970s through to the rise and fall of disco through to its mutant aftermath and the subsequent rise of house? While Rivera-Servera (2012) has developed an insightful ethnographic analysis of the Latinx dance floor that unfolded in eight clubs located in New York, Rochester, San Antonio and Austin between 1998-2003, and while José Esteban Muñoz (2009) has elucidated crucial aspects of Latinx performance in club settings, a history of the culture that locates its development within the broader conjunctural landscape of DJ-led dance culture has yet to be written. The point isn't that key Latinx figures never get to be mentioned in other accounts of queer dance culture so much as their contribution tends to be mentioned in passing, as if they were incidental, when in fact it could be argued that, to adapt Sublette's phrase, the commonplaces of Latinx music have become commonplaces of dance music.

Although it is beyond the scope of this article to provide a detailed analysis, a post-Pulse survey of DJ culture and disco during the 1970s confirms the extent of a Latinx presence that has only crept into writing on the culture. Any historical account would need to being begin with the year zero beginnings of contemporary dance music culture in 1970 when David Mancuso and Francis Grasso, spurred on by a convergent crowd that articulated 
the energies of gay liberation, civil rights, feminism, anti-war protests, the broader countercultural movement and bohemian culture, pioneered the practice that saw DJs begin to select records as part of a democratic, antiphonal conversation with the dancing crowd (Lawrence 2003). Although there were no Latin-specific discotheques in operation at the time, Latinx dancers formed a key contingent at the Loft and to a lesser extent other venues, their presence traceable to the "Great Migration" of Puerto Ricans to the US mainland during the 1950s and the passing of Hart Cellar Act in 1965, with the latter loosening up restrictions on non-European migration to the US. Their communicative presence can have only encouraged DJs to select records with varying degrees of Latinness into a mix that was largely yet by no means exclusively composed of African American recordings, with tracks such as Babe Ruth's "The Mexican", Barrabas's "Wild Safari" / "Woman”, Joe Bataan's "Latin Strut", Chakachas's "Jungle Fever”, Chicago Transit Authority's "I'm a Man”, Gil ScottHeron's "The Bottle" and WAR's "City, Country, City" offering Latin elements. Publishing the first article to point to the rising number of DJ-led dance venues in the city, Vince Aletti (1973) described the emerging sonic amalgam as "Afro-Latin in sound or instrumentation, heavy on the drums, with minimal lyrics, sometimes in a foreign language, and a repetitious chorus". How did Latin influences make themselves heard in these records? Who were the musicians and producers who spearheaded the development? What journeys did the recordings make en route to the New York dance floor? To what extent were the DJs who played them rooted in Latin culture?

Although Italian Americans dominated the formative years of the DJ profession (thanks in part to the Mafia's presence in a number of discotheques), and although African Americans such as Tee Scott and Larry Levan became increasingly influential as the decade progressed, Latinx DJs also made their mark, with David Rodriguez (the Limelight) and Richie Rivera (the Firehouse, the Anvil, Flamingo) the most notable, and John "Jellybean" Benitez, Armando Galvez, Hector Lebron, Freddie Mendoza, Mike Mora, Eddie Rivera and Ray Velazquez also significant during this period. These DJs cultivated a range of styles that articulated their diasporic subjectivities in sometimes implicit, sometimes explicit ways. Calling himself the Contessa, Rodriguez selected records with unprecedented attitude as he told tempestuous stories by interweaving the lyrics of songs (Lawrence 2003). Meanwhile the shyer Richie Rivera emerged as one of the city's most compelling DJs as he played alternate weekends at Flamingo, the most influential private party for the white gay male crowd, introducing such a high level of Latin percussion he acquired the nickname "Boom Boom Rivera". Based at the Cork \& Bottle, Eddie Rivera might have been the first DJ to introduce Latin imports into his sets, among them "El Bimbo" by the Chocolate Boys, a 1974 import (Aletti 1998: 87). Meanwhile John Benitez, whose mother migrated from Puerto Rico to the South Bronx during the early 1950s, integrated recordings such as the Latin-jazz-disco of "What You Need Is My Love" by Cindy Rodriguez (Aletti 1998: 231).

Latinx sounds became more prominent in disco during the second half of the 1970s. Van McCoy led the charge when he scored a number one hit with "The Hustle", which tapped into the revival of the Latin dance style in suburban discotheques. Formed with the idea 
of Latinising the Philadelphia Sound after its Jewish-Syrian owners had mined the Latin import market, Salsoul proceeded to bring Roy Armando, Andy Gonzalez, Manny Oquendo and Peter "Choki" Quintero as well as conga player Larry Washington into the studio, so whereas Philadelphia International house band MFSB used only one conga/timbales player (Washington), Salsoul went "very Latin", according to vibes player and producer Vince Montana (Lawrence 2003: 170). With Tom Moulton accentuating the Latin percussion in his extended mix of Patti Jo's "Make Me Believe In You", Vicki Sue Robinson heightening the percussion and flight in "Turn the Beat Around", Karen Young combining Afro-Latin rhythms with jazz and R\&B in "Hot Shot", Walter Gibbons foregrounding congas, timbales and dramatic expression in his mix of Salsoul Orchestra's "Salsoul 3001", and Richie Rivera emphasising an insistent woodblock in his mix of Anita Ward's "Ring My Bell", the kind of syncopation, colour and contrast that was more obviously typical of Cuban music than the $R \& B$ groove and swing that shaped early disco came to overtly infuse disco during the second half of the decade, with scores of other records incorporating the shift. Meanwhile Gibbons demonstrated how DJs could generate a Latin-inflected style behind the turntables when, paralleling DJ Kool Herc in the Bronx, he pioneered the technique of extending the percussive break by mixing between bongo heavy tracks such as "2 Pigs and a Hog". With the partial exception of the salsa-ification of Salsoul, these significant developments have at best been acknowledged only in passing in writing about disco.

Certain institutional gains paralleled these developments, all of them unfolding within straight settings. On the discotheque front, the Copacabana, the Cork \& Bottle and the Ipanema all targeted a Latinx crowd, with DJs such as Freddie Mendoza, Tony Gioe, Mike Mora and Eddie Rivera mixing disco with Latin tracks. As secretary of the New York Record Pool, an organisation co-founded by Mancuso to distribute free promotional records to DJs, Rivera convened a separate Latin Music Department before forming a breakaway organisation, the International Disco Record Center (IDRC). Straight Latin DJs followed Rivera while LGBTQ ones stayed with Mancuso and subsequently joined Judy Weinstein's For the Record after Mancuso wound down his pool. Lacking a night marked as their own, LGBTQ Latinx dancers continued to head to the Loft as well as other private party spaces that catered to mixed crowds, including the Gallery and the Paradise Garage. "It [the Gallery] was never clearly defined along black gay lines", notes DJ Nicky Siano of some of the non-normative aspects of Latinx queerness that require further examination (Lawrence 2003: 104). "There were so many people who were just sexual. A lot of black men would have sex with other men but didn't consider it gay sex. Puerto Rican men, who would never have been caught dead in a gay club, were 'Just hanging out, man, getting blow jobs, fucking some ass'. It wasn't about gay or straight. It was about, 'Hey, let's party!' ”

By the end of the 1970s, as a national backlash threatened to wipeout disco, Latinx protagonists could reflect that they had little to lose given that their profile was already subjugated. Admittedly the most influential New York DJ of his generation, Larry Levan of the Paradise Garage, would soon cite David Rodriguez as one of the "the school of DJs" who had most influenced him (Harvey: 30). Meanwhile Richie Rivera held down his position 
at Flamingo and Salsoul remained a hallowed label in the opinion of New York City DJs. Yet the LGBTQ Latinx dance crowd remained largely invisible to the wider public, in part because of its racial profile, in part because of the subterranean character of the private party network, while the Latinx contribution to the sound of disco barely registered as discussions framed the genre as either black (African American disco) or white (Eurodisco and the Bee Gees). It followed that when sales started to decline and the backlash gathered pace, the debate about disco's status revolved around the argument that a culture born out of African American R\&B had abandoned its roots by producing a bleached sound for a white audience. That, in turn, established the bifurcated framework that would enable the rise of rap music to be interpreted as a black working-class response to disco's journey into white commercialism, itself an oversimplified analysis of the relationship between these two sounds (Lawrence 2016). The ongoing marginalisation of the Latinx weakened the position of Eddie Rivera when he attempted to persuade the wider Latinx music community of the benefits of supporting party DJs and making records that could be played in discotheques (Fernandez 1982; Billboard 1982).

A history of Latinx dance culture that extends to the 1980s and 1990s might take account of several key developments, including the rise of John "Jellybean" Benitez as one of the most influential party DJs of the early 1980s; the contribution of Shannon's "Let the Music Play" to the emergence of freestyle as a uniquely Latin-flavoured dance floor sound, including Nayobe's breakthrough contribution; the manner in which "Little" Louie Vega made a name for himself on the New York freestyle scene before becoming one of the most influential house music DJs of the 1990s; the game-changing impact of Vega's Masters at Work and Nuyorican Soul collaboration with Kenny "Dope" Gonzalez, which saw the duo frequently team up with Latinx musicians as they established themselves as the most influential house music remix/production team of the decade; the contribution of Chicago Latinx DJs and artists, including Jesse Velez, Ralphie Rosario and Liz Torres, and New York $\mathrm{DJ} /$ producer/remixer David Morales; the pioneering role played by Cutting Records and Nervous Records when it came to showcasing Latinx house artists; the ongoing fluctuations of the New York dance floor, which included the rise of the House of Xtravaganza as the first Latinx ballroom house and the closure of the Garage; and the opening of a number of queer Latinx and cross racial party spots, including Escuelita and Suspect in Manhattan, Krash in Queens, and the Warehouse in the Bronx. Any analysis would need to consider the relationship between the straight and the queer as well as the white and the racialised. "The sexual economies of commercially driven Latin culture, generally assumed and marketed as heterosexual, are queered at the site of the local, reconfigured under a different cultural economy", notes Rivera-Servera (2004: 282). "Likewise, the often unquestioned whiteness of the gay club is challenged by the virtuoso demands of the Latina/o dancer".

Following Alexandra Vazquez's call for an analysis of Cuban music that refuses attempts to craft the country and its culture "as a fixed, immobile, and nonchanging object" (2013: 11 ), so an account of Latinx dance needs to remain alive to the borders through which the music bleeds, the instrumental combinations it stimulates and the cross-genre flights it encourages, if only because these very qualities are compelling to Latinx dance crowds 


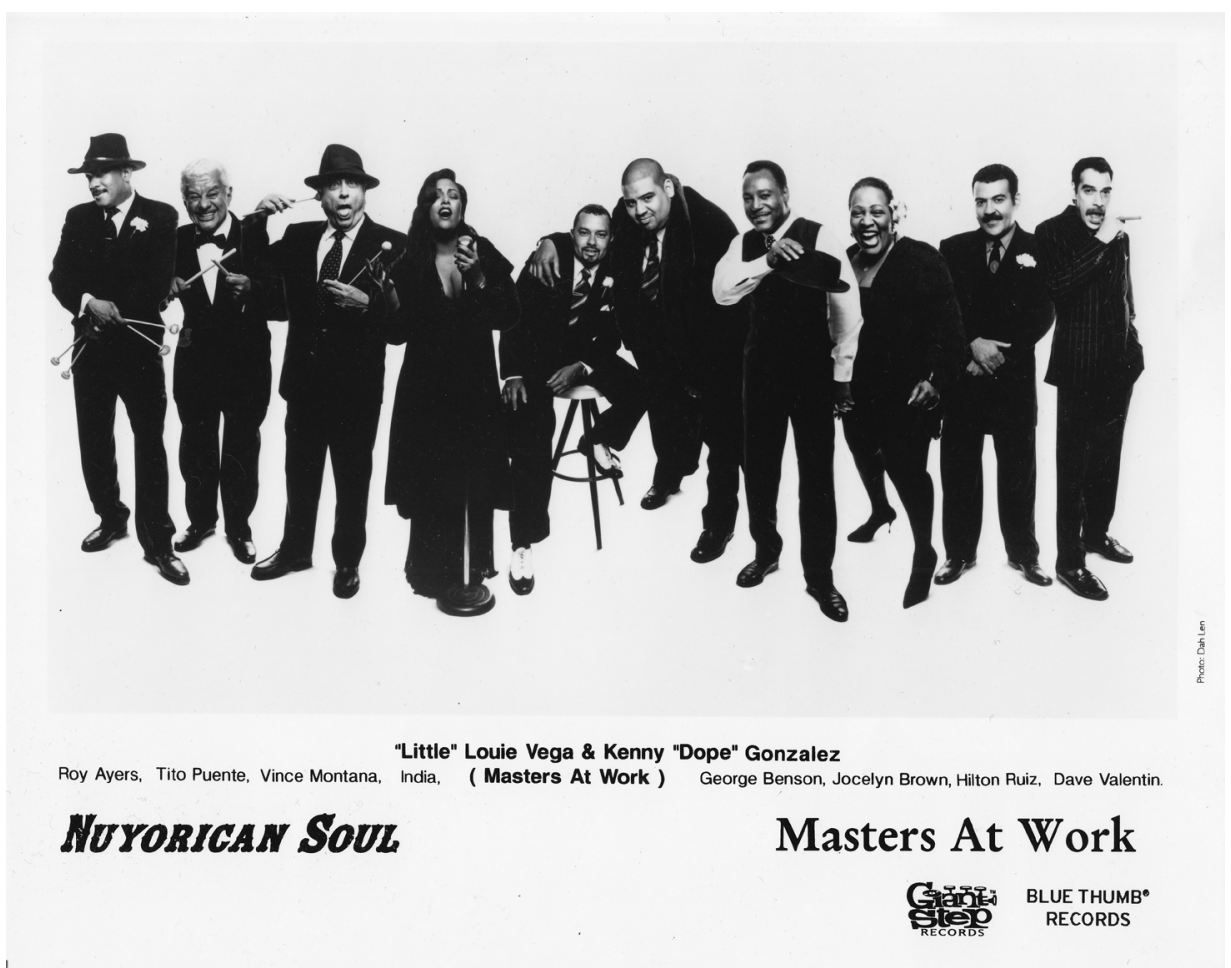

Figure 3: Nuyorican Soul led by "Little" louie Vega and Kenny "Dope" Gonzalez

that often experience life as unfixed, mobile and disjunctive. As Vazquez further suggests, we also need to listen in detail to the music, including to deceptively incidental moments in any recording, such as the sound of the woodblock in Anita Bell's "Ring My Bell", originally written and recorded by Frederick Knight for Juana as a slow track before Henry Stone, the owner of TK Productions and distributer for Juana, came to decide, perhaps through breathing the Miami air that passes from Puerto Rico and Cuba to Orlando, that the Knight record would benefit from a Richie Rivera mix (Discoguy, undated) - after which Rivera accentuated or even introduced the woodblock. As they reveal the power relations that structure how music is recorded and how it circulates, these details can inform the analysis of Latin party music while encouraging us to learn more about its submerged history-including, as I have come to understand while researching this article, that Rivera also mixed latinised disco tracks such as Melba Moore's "Standing Right Here" and Two Man Sound's "Que Tal America". How did the work of "Boom Boom Rivera" and others contribute to a viral economy of songs and moves that prepared the terrain for Pomo and others to congregate at Pulse?

If the sonic and social underpinnings of the Pulse dance floor stretch across time and space in a transglocal fashion, so do the threats that Latinx dancers face as they engage with the culture, with homophobic and racist violence hardly new, and the dance floor never straightforwardly constituted as a safe LGBTQ space. After all, until the New York law that forbade two men from dancing with one another was repealed in 1971, police officers routinely threatened to close establishments unless they received a payoff. An ensuing period 
of relative tolerance faltered when the economic slowdown of the late 1970s engendered an overtly homophobic anti-disco backlash. By 1983, as gentrification gathered pace, New York City intensified its regulation of the city's nightlife (Hae 2011) and within a couple of years a neighbourhood association forced the owner of the Paradise Garage Michael Brody to announce he would close the party when his lease expired. As crack-related violence spiralled, Brody also installed a metal detector. Meanwhile the AIDS epidemic led to a clamp down on all-male bathhouses and clubs, with Reagan's drawn-out refusal to talk about the disease widely interpreted as a sign of queer disposability. Offering no obvious respite, Mayor Giuliani clamped down on party spaces as part of his "Zero Tolerance" campaign. Throughout and beyond, dancers of all persuasions faced the threat of fire, even if the blaze at New Orleans LGBTQ hangout the UpStairs Lounge in 1973 remains the only one to have been caused by arson. Jessica Ravitz (2016) surveys other attacks carried out against queer venues, some of them successful (Eric Rudolph's bombing of a club in Atlanta in 1997), others unsuccessful (an attempted arson attack on a Seattle club in 2013). In terms of sheer concentration, however, Mateen's act remains the most violent of all and has resulted in a heightened sense of precariousness.

If the safe space of the LGBTQ dance floor has only ever been relatively safe, and if Pulse continues to welcome its LGBTQ crowd into a purpose-built environment with increased security measures, perhaps not that much will change. The Daily Beast might have introduced the strapline the "day the music died" into an article about the massacre (Suebsaeng 2016), but of course forty-nine people died on the Pulse dance floor, not the "music" or the broader desire to gather and dance to music with friends, and the commitment to continue the ritual has become pivotal to the LGBTQ community's response. "'Safe space' is a cliche, overused and exhausted in our discourse, but the fact remains that a sense of safety transforms the body, transforms the spirit", Torres (2016) notes of the culture's inevitable bounce-back. "So many of us walk through the world without it. So when you walk through the door and it's a salsa beat, and brown bodies, queer bodies, all writhing in some fake smoke and strobing lights, no matter how cool, how detached, how over-it you think you are, Latin Night at the Queer Club breaks your cool. You can't help but smile, this is for you, for us". Torres adds, poignantly: "The only imperative is to be transformed, transfigured in the disco light. To lighten, loosen, see yourself reflected in the beauty of others. You didn't come here to be a martyr, you came to live, papi. To live, mamacita. To live, hijos. To live, mariposas".

On hearing the news of the massacre, I couldn't immediately imagine how Pulse might re-open and concluded instead that the mayor of Orlando should fund the opening of a new, purpose built LGBTQ venue while converting Pulse into a museum dedicated to the victims of the massacre as well as the history of queer dance culture. Having opened the venue as a life-affirming gesture in the first place, Pomo understood much more clearly that the show had to go on, and also established the onePULSE Foundation, which is committed to contributing 90 percent of funds to the National Compassion Fund and the remaining 10 percent to the creation of a memorial. Meanwhile the Orange County Regional History Centre collected some 3,500 items related to the massacre from inside the club as well as 
spontaneous memorials. Although no quick decision will be taken on the future of the collection, some items will be included in the pre-planned exhibition "Pride, Prejudice \& Protest: GLBT History of Greater Orlando". "This touched thousands of lives", Michael Perkins, manager of the centre's museum, told the Orlando Senitel (Hudak 2016). "We are trying to preserve it for generations".

The totality of these elements show how Pulse negotiated the precarious divide between loss and creation, between violence and love, from the day it opened, and not simply the night Mateen entered the venue armed with a gun. Just as José Esteban Muñoz (2009) points to the way that queer racialised hope and loss come intertwined, with the work of building a utopia left to those whose lives have been damaged, so Pulse dancers have long been habituated to negotiating the violence of homophobia, racism and poverty. If Mateen's attack took their experience of violence to levels none of them can have imagined, the utopian worldmaking goes on because it was already mandatory, because it cannot be extinguished, and because violence breeds resourcefulness. Pulse's purpose has never been more urgent, its task to negotiating the local, the national and the transnational never clearer. At the same time, queer latinidad voices and sounds are resisting their erasure. Anger and grief are fuelling joy and resistance. As Pomo's new motto puts it, "Our hearts are broken but our Pulse is strong".

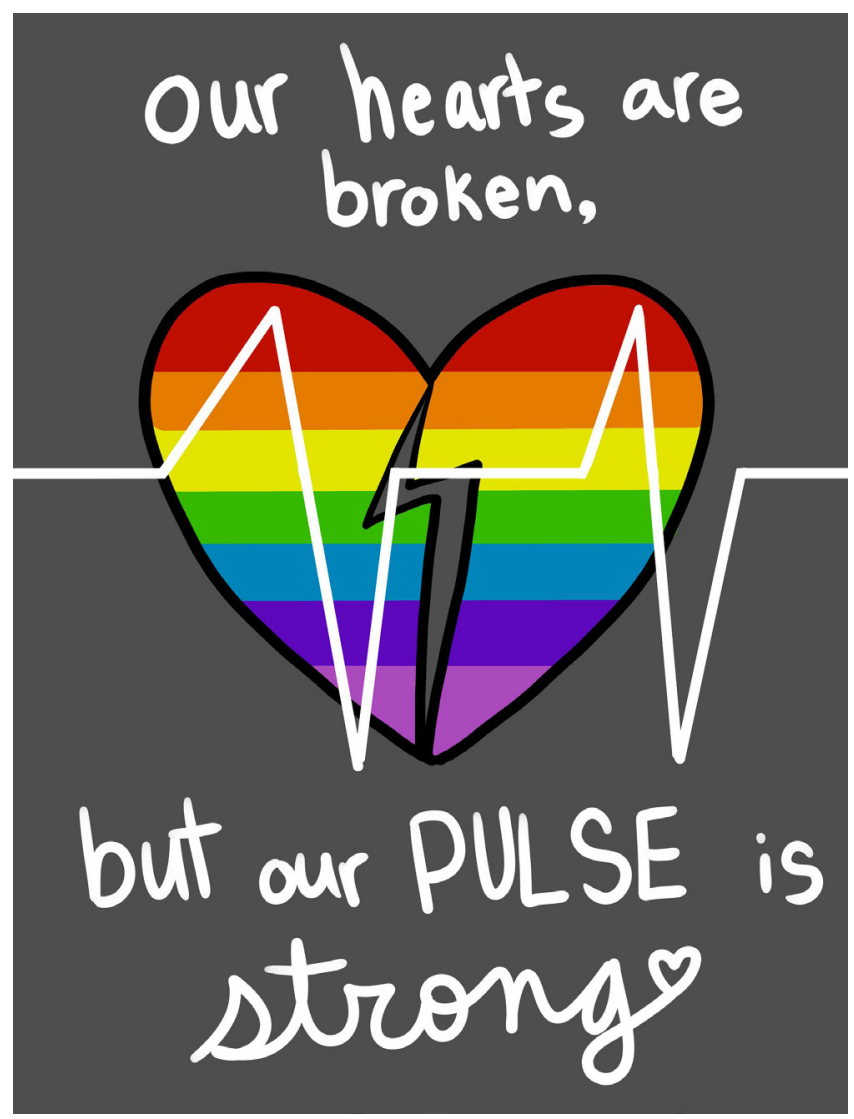

FIGURE 5: PULSE'S POST-MASSACRE FLYER.

ART BY MEGHAN MCDUNNAH: < HTTPS://WWW.FACEBOOK.COM/MMCDUNNAHART/> 


\section{ACKNOWLEDGEMENTS}

Thanks to Graham St John for encouraging this article and for comments as well as further editing suggestions by Jonathan Karpetz.

\section{NOTES}

1 Latinx is used as a gender-neutral alternative to Latino that also references agender, gender fluid, gender non-conforming, queer and trans Latin people. Like Latinidad it understands connections that exist between Latinx people without reducing them to an essential characteristic.

2 See $<$ https://www.iraqbodycount.org $>$.

3 Exceeding the idea of Latinness, or the idea of a shared geopolitical identity, the floor amounted to a Latinx space that reflected the complexities and contradictions not only of immigration, colonialism, race, colour, legal status, class, nation, language and the politics of location, but also queerness, in line with Juana María Rodríguez's framing of the queer latinidad (2003).

\section{REFERENCES}

Ackerman, Spencer, and Sabrina Siddiqui. 2016. "FBI to investigate if Orlando Gunman's Sexuality was a Motive in Shooting". Guardian, 14 June. <https://www.theguardian.com/ us-news/2016/jun/14/orlando-shooting-omar-mateen-motive-pulse-nightclub $>$. (Accessed 20 June 2016).

Ahmed, Nafeez. 2016. "How G4S Tolerated the Homophobic Hatred of Orlando's IS Terrorist". Middle East Eye, 14 June, <http://www.middleeasteye.net/columns/how-g4s-incubatedhomophobic-hatred-orlando-s-isis-terrorist-451507222 >. (Accessed 22 August 2016).

Alejandro, Jennifer. 2010. "Journalism in the Age of Social Media". Reuters Institute for the Study of Journalism, University of Oxford, < $\underline{\text { https:// reutersinstitute.politics.ox.ac.uk/sites/default/ }}$ files/Journalism\%20in\%20the\%20Age\%20of\%20Social\%20Media.pdf $>$. (Accessed 10 August 2016).

Aletti, Vince. 1998. The Disco Files 1973-78: New York's Underground, Week by Week. DJhistory. com. <http://www.djhistory.com/books/disco-files $>$.

—_— 1973. “Discotheque Rock '72 [sic]: Paaaaarty!” Rolling Stone. 13 September. (photocopy held by author)

Alvarez, Lizette. 2015. "Puerto Ricans Seeking New Lives Put Stamp on Central Florida”. 24 August, <http://www.nytimes.com/2015/08/25/us/central-florida-emerges-as-mainlandmagnet-for-puerto-ricans.html? $\mathrm{r}=1>$. (Accessed 6 September 2016).

Bendixson, Trish. "At Least Eight Queer Women Feared Dead in Orlando Gay Club Massacre". Afterellen.com, 12 June, <http://www.afterellen.com/general-news/491409-least-eight-queerwoman-dead-orlando-gay-club-massacre $>$. (Accessed 26 July 2016). 
Berman, Russell. 2016. "What's the Answer to Political Polarization in the U.S.?" The Atlantic. $8 \mathrm{March},<$ http://www.theatlantic.com/politics/archive/2016/03/whats-the-answer-topolitical-polarization/470163/>. (Accessed 26 June 2016).

Billboard, 1982. "Latin Concerts Set for Bond's". 20 March: 58. (photocopy held by author)

Blake Scott, J., and Rebecca Dingo (eds.). 2012. The "Megarhetorics" of Global Development. Pittsburgh: University of Pittsburgh Press.

Breen, Matthew. 2016. "Letter From the Editor: On Orlando and Its Aftermath". Advocate, 28 June, <http://www.advocate.com/current-issue/2016/6/28/letter-editor-orlando-and-itsaftermath $>$. (Accessed 26 July 2016).

Briefing, The. 2016. "Hillary Clinton Statement on Orlando Terrorist Attack". Undated. < https://www.hillaryclinton.com/briefing/statements/2016/06/13/hillary-clintonstatement-on-orlando-terrorist-attack/>. (Accessed 27 June 2016).

Broverman, Neal. 2016. "Congress Sticks It to Gays on Anniversary of Pulse Massacre”. Advocate, 12 July, < http://www.advocate.com/politics/2016/7/11/congress-sticks-it-gays-anniversarypulse-massacre $>$. (Accessed 26 July 2016).

Browne, Rachel. 2016. “It Affects Us All': Vigils Held Around the World for Victims of Orlando Nightclub Massacre”. Vice News. 13 June, <https://news.vice.com/article/it-affects-us-allvigils-around-the-world-for-victims-of-orlando-nightclub-massacre $>$. (Accessed 26 July 2016).

Chamseddine, Roqayah. 2016. Contribution to "After Orlando". Middle East Research and Information Project. 17 June, <http://www.merip.org/after-orlando>. (Accessed 26 July 2016.

Chappatta, Brian. 2016. "Puerto Rico Economy Worsens With Crisis, Most Anywhere You Look". Bloomberg. 25 April, <http://www.bloomberg.com/politics/articles/2016-04-25/ puerto-rico-economy-worsens-with-crisis-most-anywhere-you-look $>$. (Accessed 28 July 2016).

Discoguy. (Undated). "This is a Tribute to.... T.K. Productions". < $\underline{\text { disco-disco.com. http://www. }}$ disco-disco.com/labels/tkdisco.shtml >. (Accessed 14 August 2016).

Fernandez, Enrique. 1982. "Mercado's Record Pool Is New Force in Latin Mart”. Billboard, 21 August: 54, 58, (photocopy held by author).

Foiles Sifuentes, AM. 2016. "A Preemptive Strike: Cannibalizing Queer People of Color in the Aftermath of the Orlando Massacre". 21 June, <http://www.thefeministwire.com/2016/06/ cannibalizing-queer-people-color-aftermath-orlando-massacre/>. (Accessed 26 July 2016).

Fry, Courtney. 2016. “The Orlando Shootings Are a Threat to Queer Safe Spaces Everywhere”. Junkee.com. 13 June, <http://junkee.com/the-orlando-shootings-are-a-threat-to-queer-safespaces-everywhere/80525>. (Accessed 26 July 2016).

Goldman, Adam. 2016. "FBI Has Found No Evidence That Orlando Shooter Targeted Pulse Because It Was a Gay Club". Washington Post. 16 July, < https://www.washingtonpost.com/ world/national-security/no-evidence-so-far-to-suggest-orlando-shooter-targeted-clubbecause-it-was-gay/2016/07/14/a7528674-4907-11e6-acbc-4d4870a079da story.html>. (Accessed 26 July 2016).

Gray, Tyler. 2016. "Pulse Owner Barbara Poma on Why the Orlando LGBT Nightclub Stood Out in the Land of Disney". 22 June, <http://www.billboard.com/articles/news/7415614/ barbara-poma-pulse-owner-orlando-shooting>. (Accessed 6 September 2016). 
Green, Emma. 2016. “The Extraordinarily Common Violence Against LGBT People in America". Atlantic. 12 June, <http://www.theatlantic.com/politics/archive/2016/06/theextraordinarily-common-violence-against-lgbt-people-in-america/486722/>. (Accessed 26 August 2016).

Guardian. 2016. "Florida Shooting: Two Dead and up to 17 Injured Outside Fort Myers Nightclub”. 25 July, <https://www.theguardian.com/us-news/2016/jul/25/shootingnightclub-fort-myers-florida $>$. (Accessed 14 August 2016).

Hae, Laam. 2011. "Dilemmas of the Nightlife Fix: Post-industrialization and the Gentrification of Nightlife in New York City”. Urban Studies. April 11: 1-17. < http://dx.doi.org/ $\underline{10.1177 / 0042098011400772>\text {. }}$

Halberstam, Jack. 2016. “Who Are 'We' After Orlando?” Bully Bloggers. 22 June, <https:// bullybloggers.wordpress.com/2016/06/22/who-are-we-after-orlando-by-jack-halberstam/>. (Accessed 26 July 2016).

Hanhardt, Christina B. 2012. "Left Queer". Scholar \& Feminist Online. 11.1-11.2, Fall 2012/ Spring 2013, < http://sfonline.barnard.edu/gender-justice-and-neoliberal-transformations/>.

Harvey, Steven. 1983. "Behind the Groove”. Collusion. September: 26-33, original held by author.

Hudak Stephen. 2016. "Museum Curators Gather, Preserve Pulse History”. 3 September, $<$ http://www.orlandosentinel.com/news/pulse-orlando-nightclub-shooting/os-pulse-orangehistory-center-collection-20160902-story.html >. (Accessed 5 September 2016).

Kornhaber, Spencer. 2016. “The Singular Experience of the Queer Latin Nightclub”. Atlantic. 17 June, <http://www.theatlantic.com/entertainment/archive/2016/06/orlando-shootingpulse-latin-queer-gay-nightclub-ramon-rivera-servera-intrerview/487442/>. (Accessed 26 July 2016).

Kronstad, Jens Manuel, and Jeffrey S. Passel. 2015. "5 Facts about Illegal Immigration in the U.S.” 19 November, <http://www.pewresearch.org/fact-tank/2015/11/19/5-facts-about-illegalimmigration-in-the-u-s/>. (Accessed 10 August 2016).

Lawrence, Tim. 2011. "Disco and the Queering of the Dance Floor". Cultural Studies, 25(2): 230-43. <http://dx.doi.org/10.1080/09502386.2011.535989>.

- - 2016. Life and Death on the New York Dance Floor, 1980-83. North Carolina: Duke University Press.

- - 2003. Love Saves the Day: A History of American Dance Music Culture, 1970-79. North Carolina: Duke University Press.

Leon-Davis, Daniel. 2016. “The Site of the Orlando Shooting Wasn't Just a Gay Nightclub. It Was My Safe Haven”. Fusion. 12 June, < http://fusion.net/story/312960/pulse-orlando-safehaven/>. (Accessed 26 July 2016).

Mason, Everdeen, Aaron Williams and Kennedy Elliott. 2016. “The Dramatic Rise in State Efforts to Limit LGBT Rights”. Washington Post. 1 July, < https://www.washingtonpost.com/ graphics/national/lgbt-legislation/>. (Accessed 22 August 2016).

McCarthy, Jim, and Ron Sansoe. 2005. Voices of Latin Rock: The People and Events That Created This Sound. Minnesota: Hal Leonard Corporation. 
McMains, Juliet. 2015. Spinning Mambo into Salsa: Caribbean Dance in Global Commerce. Oxford: Oxford University Press.

Mikdashi, Maya. 2016. Contribution to "After Orlando". Middle East Research and Information Project. 17 June, <http://www.merip.org/after-orlando>. (Accessed 26 July 2016).

Mirkinson, Jack, Casey Tolan and Danielle Wiener-Bronner. “These Are the Victims of the Orlando Massacre”. Fusion. 12 June, <http://fusion.net/story/313038/orlando-shootingvictims-names-pulse-massacre/>. (Accessed 26 July 2016).

Muñoz, José Esteban. 2009. Cruising Utopia: The Then and There of Queer Futurity. New York: NYU Press.

New York Times. 2016. "Florida Shooting: Live Updates: Statement from Rep. Adam Schiff, Ranking Member of the House Intelligence Committee”. 12 June, < $\underline{\text { http://www.nytimes.com/ }}$ live/orlando-nightclub-shooting-live-updates/statement-from-r/ >. (Accessed 26 July 2016).

O’Doherty, Ian. 2016. “Orlando 'Pulse' Nightclub Attack Was More Charlie Hebdo than Columbine”. Irish Independent. 14 June, < http://www.independent.ie/opinion/columnists/ ian-odoherty/ian-odoherty-orlando-pulse-nightclub-attack-was-more-charlie-hebdo-thancolumbine-34798687.html >. (Accessed 26 July 2016).

Ong, Aihwa. 1999. Flexible Citizenship: The Cultural Logics of Transnationality. Durham: Duke University Press.

Park, Haeyoun, and Iaryna Mykhyalyshyn. 2016. "L.G.B.T. People Are More Likely to Be Targets of Hate Crimes Than Any Other Minority Group". New York Times, 16 June, < http://www. nytimes.com/interactive/2016/06/16/us/hate-crimes-against-lgbt.html >. (Accessed 21 August 2016).

Puar, Jasbir K. 2007. Terrorist Assemblages: Homonationalism in Queer Times. Durham and London: Duke University Press. <http://dx.doi.org/10.1215/9780822390442>.

Puar, Jasbir K., and Amit Rai. 2002. "Monster, Terrorist, Fag: The War on Terrorism and the Production of Docile Patriots". Social Text 20(3): 117-48. < http://dx.doi. org/10.1215/01642472-20-3 72-117>.

Ravtiz, Jessica. 2016 "Before Orlando: The (Former) Deadliest LGBT Attack in U.S. History". CNN. 19 June, <http://edition.cnn.com/2016/06/16/health/1973-new-orleans-gay-bararson-attack/>. (Accessed 21 August 2016).

Rich, Adrienne. 1994. “Compulsory Heterosexuality and Lesbian Existence (1980)”. In Blood, Bread, and Poetry. London: W.W. Norton.

Rivera, Raquel. 2003. New York Ricans from the Hip Hop Zone. New York: Palgrave Macmillan.

Rivera, Raquel, Wayne Marshall and Deborah Pacini (eds). 2009. Reggaeton. North Carolina: Duke University Press.

Rivera, Ray. 2016. Facebook exchange with Tim Lawrence, 29-30 August.

Rivera-Servera, Ramón H. 2012. Performing Queer Latinidad: Dance, Sexuality, Politics. Ann Arbor: University of Michigan Press

- - - 2004. "Choreographies of Resistance-Latina/o Queer Dance and the Utopian Performative”. Modern Drama, 47 (2): 269-89. <http://dx.doi.org/10.3138/md.47.2.269>.

Rodríguez, Juana María. 2003. Queer Latinidad Identity Practices, Discursive Spaces. New York: NYU Press. 
Rodriguez, Matthew. 2016. Orlando’s Gay Latino Community Describes Pulse Nightclub in Their Own Words", 18 June, <https://mic.com/articles/146457/orlando-s-gay-latinocommunity-describes-pulse-nightclub-in-their-own-words\#.aquNrViBa >. (Accessed $26 \mathrm{July}$ 2016).

Rondón, César Miguel. 2008. The Book of Salsa: A Chronicle of Urban Music from the Caribbean to New York City. Chapel Hill: University of North Carolina Press.

RT.com. 2016. "FBI Calls Orlando Massacre both Hate Crime \& Terrorism”. 15 June, $<\underline{\text { https:// }}$ www.rt.com/usa/346848-fbi-orlando-hate-crime-terrorism/>. (Accessed 26 July 2016).

Said, Edward W. 1995. Orientalism. London: Penguin Books.

Salvanto, Anthony, and Fred Backus, Sarah Dutton and Jennifer De Pinto. 2016. "Gauging Americans' Views on Orlando Mass Shooting”. cbsnews.com, 15 June, < $\underline{\text { http://www.cbsnews. }}$ com/news/orlando-mass-shooting-poll-trump-obama-clinton-reaction/>. (Accessed $28 \mathrm{July}$ 2016).

Shabad, Rebecca. 2016. "FBI Director Comey: "Highly Confident" Orlando Shooter Radicalized through Internet”. CBS News. 13 June, <http://www.cbsnews.com/news/fbi-director-comeyhighly-confident-orlando-shooter-radicalized-through-internet/>. (Accessed 28 July 2016).

Shakhsari, Sima. 2016. Contribution to "After Orlando". Middle East Research and Information Project. 17 June, < http://www.merip.org/after-orlando >. (Accessed 26 July 2016).

Shear, Michael D. (2016). "After Nightclub Massacre, Obama Expresses Outrage and a Familiar Lament”. New York Times. 12 June, <http://www.nytimes.com/2016/06/13/us/politics/ president-obama-expresses-outrage-over-massacre-at-nightclub.html $>$. (Accessed 21 August 2016).

Storm-Roberts, John. 1999. The Latin Tinge. Oxford: Oxford University Press.

Sublette, Ned. 2004. Cuba and Its Music. Chicago: Chicago Review Press.

Suebsaeng, Asawin. 2016. "Pulse DJ Saved Lives Behind His Booth as Gunfire Tore Into Club". Daily Beast. 12 June, < http://www.thedailybeast.com/articles/2016/06/12/pulse-djdescribes-orlando-massacre-everybody-was-just-panicking.html >. (Accessed 21 August 2016>.

Sullivan, Kevin, and William Wan. 2016. "Troubled. Quiet. Macho. Angry. The Volatile Life of the Orlando Shooter". Washington Post. 17 June, <https://www. washingtonpost.com/national/troubled-quiet-macho-angry-the-volatile-life-of-omarmateen/2016/06/17/15229250-34a6-11e6-8758-d58e76e11b12_story.html>. (Accessed 18 August 2016).

Teague, Matthew, Ciara McCarthy and Nicole Puglise. 2016. "Orlando Attack Victims: The Lives Cut Short in America's Deadliest Shooting”. 13 June, <https://www.theguardian. com/us-news/ng-interactive/2016/jun/13/orlando-terror-attack-victims-pulse-nightclub $>$. (Accessed 20 July 2016).

Time. 2016. "Read President Obama's Speech on the Orlando Nightclub Shootings". 12 June, <http://time.com/4365454/orlando-shooting-president-obama-speech-transcript/>. (Accessed 26 July 2016).

Torres, Justin. 2016. "In Praise of Latin Night at the Queer Club". Washington Post. 13 June, $<$ https://www.washingtonpost.com/opinions/in-praise-of-latin-night-at-the-queerclub/2016/06/13/e841867e-317b-11e6-95c0-2a6873031302 story.html?utm term=. cb39784b4173>. (Accessed 26 July 2016). 
Trump, Donald. 2016. "Donald J. Trump Addresses Terrorism, Immigration, and National Security". 13 June, <https://www.donaldjtrump.com/press-releases/donald-j.-trumpaddresses-terrorism-immigration-and-national-security $>$. (Accessed 26 July 2016).

——-. 2016. Twitter post. 5:43pm, 12 June, <https://twitter.com/realdonaldtrump/ status/742034549232766976>. (Accessed 26 July 2016).

Univision. 2016. “Transcript of Interview with Man Who Claims to be Former Lover of Orlando Gunman”. 22 June, <http://www.univision.com/univision-news/transcript-of-interview-withman-who-claims-to-be-former-lover-of-orlando-gunman>. (Accessed 26 July 2016).

Vasquez, Tina. 2016. "Reimagining Safety for Queer and Trans Communities in Wake of Orlando". Rewire. 23 June, <https://rewire.news/article/2016/06/23/reimagining-safetyqueer-trans-communities-wake-orlando/>. (Accessed 26 July 2016).

Vazquez, Alexandra T. 2013. Listening in Detail: Performances of Cuban Music. North Carolina: Duke University Press.

Waters, Emily, and Chai Jindasurat, Cecilia Wolfe. 2016. "Lesbian, Gay, bisexuaL, Transgender, Queer, and HIV-affected Hate Violence in 2015". National Coalition of Anti-violence Programs, <http://www.avp.org/storage/documents/ncavp hvreport 2015 final.pdf $>$. (Accessed 21 August 2016).

Wikipedia. 2016. "Pulse (nightclub)". < https://en.wikipedia.org/wiki/Pulse_(nightclub)>. (Accessed 21 August 2016).

Wolf, Colin. 2016. "Nearly 48 Hours Later, Florida Gov. Rick Scott Finally Acknowledges the LGBT Community”. Orlando Weekly. 14 June, < http://www.orlandoweekly.com/Blogs/ archives/2016/06/14/nearly-48-hours-later-florida-gov-rick-scott-finally-acknowledges-thelgbt-community >. (Accessed 21 August 2016).

Wyatt, Diego. 2016. “The Pulse of Orlando”. Next Magazine. 3 February, <http://nextmagazinefl. com/central-florida/the-pulse-of-orlando >. (Accessed 21 August 2016).

DISCOGRAPHY

Babe Ruth. 1973. “The Mexican”. Odeon (LP): 3351. <https://www.discogs.com/Babe-Ruth-First-Base/release/6541665>.

Barrabas. 1972. "Wild Safari" and "Woman". Wild Safari. RCA Victor (LP): 443.043. <https://www.discogs.com/Barrabas-Wild-Safari-Afro-Soul/release/617339>.

Joe Bataan. 1974. "Latin Strut”. Mericana Records (7-inch single): M-7157. <https://www.discogs.com/Joe-Bataan-Latin-Strut-Peace-Friendship-And-Solidarity/ release/867207>.

Chakachas. 1971. "Jungle Fever". Polydor (7-inch single): PD-15030. <https://www.discogs.com/The-Chakachas-Jungle-Fever/release/2069961>.

Chocolate Boys. 1974. “El Bimbo”. Les Disques Fleur Inc. (7-inch single): FL 479. <https://www.discogs.com/Chocolate-Boys-El-Bimbo-Voltaire-Pier/release/8354579>.

Chicago Transit Authority. 1969. "I'm a Man". Chicago Transit Authority. Columbia (LP): GP 8. $<$ https://www.discogs.com/Chicago-Transit-Authority-Chicago-Transit-Authority/ release $/ 9195483>$. 
Cindy Rodriguez. 1976. "What You Need Is My Love”. Disko-Mania (12-inch single): DL-557. <https://www.discogs.com/Cindy-Rodriguez-What-You-Need-Is-My-Love-Phoenix/ release $/ 2863913>$.

Patti Jo. 1975. "Make Me Believe In You”. Disco Gold (remixed by Tom Moulton). Sceptre Records (LP): SPS 5120. <https://www.discogs.com/Various-Disco-Gold/release/1052277>.

Van McCoy. 1975. “The Hustle”. Avco Records (7-inch single): AV 4653. $<$ https://www.discogs.com/Van-McCoy-The-Soul-City-Symphony-The-Hustle-Hey-GirlCome-And-Get-It/release/263503>.

Vicki Sue Robinson. 1976. “Turn the Beat Around”. RCA Victor (7-inch single): PB 10562. $<$ https://www.discogs.com/Vicki-Sue-Robinson-Turn-The-Beat-Around-Lack-Of-Respect/ release $/ 692440>$.

Salsoul Orchestra, The. 1976. "Salsoul 3001". Salsoul Records (12-inch single): 12D-2011. <https://www.discogs.com/Salsoul-Orchestra-Nice-N-Naasty/release/75606>.

Shannon. 1983. "Let the Music Play". Emergency Records (12-inch single): EMDS 6540. <https://www.discogs.com/Shannon-Let-The-Music-Play/release/66766>.

Gil Scott-Heron/Brian Jackson. 1974. “The Bottle”. Strata-East (7-inch single): SES-19742-45. $<$ https://www.discogs.com/Gil-Scott-Heron-Brian-Jackson-The-Bottle/master/7833 >.

WAR. 1972. "City, Country, City”. The World Is a Ghetto. United Artists Records (LP): UAS-5652. <https://www.discogs.com/War-The-World-Is-A-Ghetto/release/428062>.

Anita Ward. 1979. “Ring My Bell (Midnight Mix)”. T.K. Disco (12-inch single): 124. <https://www.discogs.com/Anita-Ward-Ring-My-Bell/release/2906909>.

Karen Young. 1978. "Hot Shot". West End Records (12-inch single): WES 12111. <https://www.discogs.com/Karen-Young-Hot-Shot/release/79289>. 